\title{
CORPORATE GOVERNANCE \& AUDITOR CHOICE IN MALAYSIA
}

\author{
Wan Asma Wan Nasrudin*, Norhayati Mohamed, Nur Aima Shafie \\ Universiti Teknologi Mara
}

\begin{abstract}
The aim of this paper is to investigate the determinants of firm's auditor choice in Malaysia in respect of their corporate governance mechanisms. A logit regression model was developed to test the impact of firms' internal corporate governance mechanism on auditor choice decisions made by public listed companies listed on main board of Bursa Malaysia from year 2006 to 2015. Five variables are used to proxy for firm's internal corporate mechanism which are the ownership concentration, the duality of CEO and chairman of BOD, the size of audit committee, the size of BOD and the number of independent directors on the board. All auditors in Malaysia were classified into Big Four and non-Big Four, assuming Big Four auditors can provide higher quality audit services. The final result show that firms with less concentrated ownership, with larger size of audit committee, larger size of the BOD, with lower proportion of independent directors on the board, or in which CEO and BOD's chairman are not the same person are more likely to hire a high-quality auditor. Hence, it suggests that when benefits from lowering capital raising costs are trivial, firms with good corporate governance mechanism are prone to choose a high-quality auditor.
\end{abstract}

Keywords: Corporate Governance, Auditor Choice, Logit Regression, Firm Risk, Largest Ownership

\section{INTRODUCTION}

This paper studies the role of internal corporate governance mechanisms as the deciding factors that determine auditor choice decision in Malaysia. This study is inspired by the growing body of researches that scrutinizes auditor choice decision (Ahmad, Houghton and Yusof, 2006; Beattie and Fearnley, 1995; Chaney, Jeter and Shivakumar, 2003; Guedhami, Pittman and Saffar, 2009; Hope, Kang, Thomas and Yoo, 2008; Johnson and Lys, 1990; Linda Elizabeth, 1982; Mahdavi, Maharlouie, Ebrahimi and Sarikhani, 2011; Pittman and Fortin, 2004; Wang, Wong and Xia, 2008).

Prior study (Fields, Lys and Vincent, 2001), mentions that financial disclosure and reporting are essential in order to address the imperfections and incomplete financial asymmetry within the financial world. Information asymmetries in general are related with the bond between managers and investors in which managers who are better informed tend to disseminate less information to

*Corresponding author' email: wan9513@ns.uitm.edu.my 
investors. Nurwati and Wan Nordin (2010) stress that to minimize agency problems, what is needed is to reduce the information asymmetry between management and shareholders, which can be gained through transparent financial disclosure. In addition, the after effect of corporate scandals such as the Enron shocking incident and other current financial crisis further lead the policy makers and regulators to draw more attention to the needs for a better quality and more transparent financial reporting (Bardos, 2011).

\section{LITERATURE REVIEW}

\section{CORPORATE GOVERNANCE IN MALAYSIA}

Prior study such as that by Alnasser (2012) notes that corporate government scandals have persuaded scholars to give meaning to corporate governance based on their perspectives on problem solving and corporate affairs. As such, a common definition sets down that internal governance mechanisms take into account elements that relates to the firm's internal organizational structure, such as, board of directors and ownership structure while the external governance mechanisms includes taking over the markets and the legal system.

The turning point of corporate governance reformation in Malaysian was after the Asian financial crisis in 1997 (Alnasser, 2012; Kamardin and Haron, 2011; MCCG, 2012). The outbreak of the crisis taught the policy makers valuable lessons and placed their attention, amongst others, on the necessity to raise corporate governance standards. It pointed out the weaknesses in governance practices and made it clear for the need to establish a more responsible, and transparent management in step with international best practices.

Seeing how corporate governance has become an essential part of the Malaysian business environment, it is therefore important to study the relative influence it has on firms' decisions and performances. One particular matter is its implication on auditor choice decision as many prior studies have delved into the association between these two variables (Guedhami, et al., 2009; Lin and Liu, 2009; Mahdavi, et al., 2011; Wang, et al., 2008).

\section{CORPORATE GOVERNANCE, AUDITOR DEMAND AND AUDITOR CHOICE}

The interrelations between corporate governance and auditor choice have been the issue of many prior discussions and studies. Mahdavi, et al. (2011) look into the influence of corporate governance mechanisms on auditor choice among Iranian listed firms. They explore the impact of ownership structure, concentration of ownership, board composition and duality of the CEO and chairman roles as the proxies of corporate governance mechanisms on firms' auditor choice decisions. The researchers conclude that the corporate governance mechanisms make a difference to the choice of auditor in firms listed on Tehran Stock Exchange, where the possibility of a high-quality audit firm being chosen will increases in line with the percentage of outside directors. 


\section{AUDITOR AND AUDIT QUALITY}

Based on previous research paper on Malaysian corporate governance, there are three classifications of people that act as "external enforcers" of good governance identified by The Finance Committee: the auditors, corporate advisers and regulators. In other words, auditors perform a corporate governance role in monitoring a firm's financial reporting process, or they act as "watchdogs" of the firms (Ashbaugh and Warfield, 2003). Audit function plays a crucial role not only to monitor managerial actions but also to create a better information environment as well as to provide a secondary source of assurance against corporate failures (Wallace, 2004). As such, auditors are required to give appropriate assurance through their opinions on whether the firms' annual accounts have been properly drawn up and in compliance with the approved standards, and if they portray a true and fair view of the firms' affairs.

\section{CORPORATE GOVERNANCE PROXIES}

\section{OWNERSHIP CONCENTRATION AND AUDITOR CHOICE}

In Malaysian public listed firms, shareholding is highly concentrated in the hands of small number shareholders (La Porta, Lopez-de-Silanes, Shleifer and Vishny, 2000; Samad, 2002). Samad (2002) reports that the average of the first largest shareholding was 30.30 percent and the five largest shareholdings were 58.84 percent, which accounted for more than half of the voting shares. Furthermore, Kamardin and Haron (2011) mention that around 71.4 percent of firms on the Main Board and Second Board of Bursa Malaysia were controlled by their five largest shareholders, having a shareholding of more than 50 percent and were under majority ownership.

\section{SIZE OF AUDIT COMMITTEE AND AUDITOR CHOICE}

The audit committee is fundamental to the concept of corporate accountability and sound governance. It has become an integral part of the corporate framework to help fulfil board's stewardship accountability to its shareholders and financial stakeholders. An audit committee provides the board with assurance of the quality and reliability of financial information used by the board and of the financial information issued publicly by the firm. Although the board as a whole is responsible for the accuracy and integrity of the firm's financial reporting, it can be difficult for all directors to keep up with the complexities of financial reporting. That is where the role of the audit committee emerges as it provides an additional and more specialized oversight of the financial reporting process by facilitating the discharge of the board's responsibility with respect to the timely preparation and issuance of financial statements (MCCG, 2012).

\section{DUALITY OF ROLES OF BOD CHAIRMAN AND CEO, AND AUDITOR CHOICE}

The Companies Act, 1965 (CA) states that the business and affairs of a firm must be managed by, or under the direction of, the Board of Directors (BOD). The BOD is obligated to play an active role in directing management. While this does not mean they should be involved in operational matters, it certainly implies that board cannot passively endorse decisions of the 
management. As such the BOD's role is to provide entrepreneurial leadership of the company within a framework of prudent and effective controls, which enable risk to be assed and managed.

\section{SIZE OF BOARD OF DIRECTORS AND AUDITOR CHOICE}

Due to limitations of corporate structure since its inception, shareholders take a precaution step by appointing representative to serve their interests. These shareholders advocates took the form of the "Corporate Board of Directors" whose responsibilities were to meet with and oversee the management of the entity and look out for the interest of the owners. The role of the board is often referred to as the role of steward whose the main responsibility was to ensure the interest of shareholders has been taken care of (Eugene A. Imhoff, 2003). The BOD is the key decision makers in the organization and they have the power to atone the whole decisions that are made by the top management. Furthermore, they said that, in the process of decision-making, the initiation and implementation should be separated from the ratification and monitoring of the decisions in order to make sure the efficient monitoring functions.

\section{NUMBER OF INDEPENDENT DIRECTORS AND AUDITOR CHOICE}

Independence of board influences the extent to which the board is independent of company management. A number of studies document a positive relationship between board independence and actions that are in the best interest of shareholders. The BOD is the best control mechanism to monitor actions of management. The study explored board independence based on the agency theory. Outside directors have a motivation to monitor management because the value of their own human capital is partially determined by the effectiveness of their monitoring performance. Thus, independent (outside) directors are more willing to provide effective oversight. They also proposed that the proportion of independent directors on the board was negatively related to the likelihood of financial reporting fraud.

\section{RESEARCH METHODOLOGY}

\section{HYPOTHESIS DEVELOPMENT}

The objective of this study is to examine the effect of corporate governance mechanisms toward public listed firms' auditor choice decisions. Thus, five main hypotheses have been developed.

Hypothesis 1 (H1): The higher the percentage of total shares held by the largest owner, the less likely a firm will choose a high-quality (Big Four) auditor, ceteris paribus.

Hypothesis $2(\mathrm{H} 2)$ : The fewer the number of the audit committee members, the less likely a firm will choose a high-quality (Big Four) auditor, ceteris paribus.

Hypothesis 3 (H3): When the same persons hold the positions of CEO and BOD chairman, it is less likely a firm will choose a high-quality auditor (Big Four) auditor, ceteris paribus. 
Hypothesis 4 (H4): The bigger the size of BOD, the less likely a firm will choose a high-quality (Big Four) auditor, ceteris paribus

Hypothesis 5 (H5): The fewer the number of the independent directors, the less likely a firm will choose a high-quality (Big Four) auditor, ceteris paribus

\section{SAMPLE SELECTION AND DATA COLLECTION}

For the sample, public listed firms on the Main Market of Bursa Malaysia during the period of 2010-2015 were initially considered. The list of the firms was obtained from the Bursa Malaysia web site (http://www.bursamalaysia.com). In total, the sample population contained approximately 810 listed firms (List updated as at 31 August 2016). From there, the final target sample were selected down to 261 firms. Table 1 shows the summary of variables used in this study.

Table 1: Summary of Variables

\begin{tabular}{clcc} 
NO & \multicolumn{1}{c}{ VARIABLES } & ABBREVIATIONS & $\begin{array}{c}\text { SOURCE OF DATA } \\
\text { Data Stream (DS) / Annual Report (AR) }\end{array}$ \\
& & & $\mathrm{AR}$ \\
1 & Auditor choice & AUD & AR \\
2 & Largest ownership & LSH & AR \\
3 & No of audit committee member & AC & AR \\
4 & Duality of CEO & DUALITY & AR \\
5 & No of BOD & BOD & AR \\
6 & No of independent director & NED & DS \\
7 & Firm size (Log of total assets) & ATR & DS \\
8 & Firm growth (Asset turnover ratio) & ROA & DS \\
9 & Firm profitability (Return on assets) & CURR & DS \\
10 & Firm asset structure (Current assets ratio) & DA & DS \\
11 & Firm leverage (Debt to asset ratio) & BETA & DS \\
12 & Firm risk (Beta) & &
\end{tabular}

\section{MODEL SPECIFICATION AND VARIABLE DEFINITIONS}

In this study, following Lin and Liu (2009), a binary classification was used to divide auditors in Malaysia into two categories. This study identifies Big Four Malaysian audit firms as Deloitte, Ernst and Young, KPMG and PricewaterhouseCoopers (PWC).

Since the dependent variable, auditor choice, is binary in nature (Big Four versus non-Big Four), following Lin and Liu (2009), this model uses logit regression to test the hypotheses of the relationship between corporate governance variables and auditor choice. The model is as specified below.

AUD $={ }_{\beta} 0+{ }_{\beta} 1 \mathrm{LSH}+{ }_{\beta} 2 \mathrm{AC}+{ }_{\beta} 3 \mathrm{DUALITY}+{ }_{\beta} 4 \mathrm{BOD}+{ }_{\beta} 5 \mathrm{NED}+{ }_{\beta} 6 \mathrm{LNASSET}+{ }_{\beta} 7 \mathrm{ATR}+$ ${ }_{\beta} 8 \mathrm{ROA}+{ }_{\beta}$ 9CURR $+{ }_{\beta} 10 \mathrm{DA}+{ }_{\beta} 11 \mathrm{BETA}+\varepsilon$

Where,

AUD $=1$ if the auditor is a Big Four auditor; 0 otherwise 


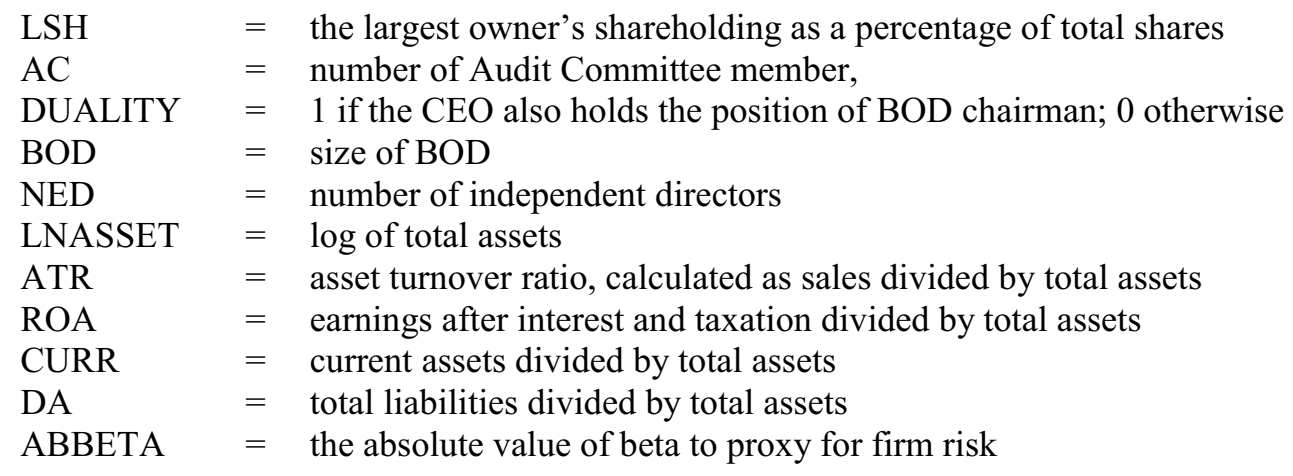

This model tested the association between the internal corporate governance mechanisms of the public listed Malaysian firms and their auditor choice decision as whether firms with strong internal corporate governance mechanisms would be more likely to choose auditors of high quality. In relation to the five hypotheses, it is predicted that the sign of coefficient for hypotheses " 1,3 and 4" will be negative while for hypotheses " 2 and 5" will be positive. This study controls for firm size (log of total asset), growth (asset turnover ratio), profitability (return on asset), asset structure, (current asset divided by total asset), financial leverage (total liabilities divided by total asset) and firm risk (beta) in the model.

\section{EMPIRICAL FINDINGS}

\section{DESCRIPTIVE STATISTICS}

The data collected are analyzed using Statistical Package for Social Science (SPSS). Descriptive statistic is useful to describe the data or see the characteristics of the data. It provides simple summaries about the sample and about the observations that have been made. Table 2 and Table 3 represent descriptive statistics results and correlation matrix of independent variables consecutively.

Table 2: Descriptive Statistics

\begin{tabular}{lrrrrrr} 
& $\mathrm{N}$ & \multicolumn{1}{c}{ Minimum } & Maximum & Mean & Std. Deviation & Variance \\
\hline AUDITOR CHOICE & 1566 & 0 & 1 & .62 & .486 & .236 \\
LARGEST OWNERSHIP & 1566 & 1.660 & 73.370 & 28.43657 & 16.333257 & 266.775 \\
NO OF AUDIT COMMITTEE MEMBER & 1566 & 3 & 6 & 3.37 & .637 & .406 \\
DUALITY OF CEO & 1566 & 0 & 1 & .23 & .418 & .175 \\
NO OF BOD & 1566 & 3 & 17 & 7.47 & 1.989 & 3.957 \\
NO OF INDEPENDENT DIRECTOR & 1566 & 1 & 7 & 3.18 & .985 \\
LNASSET & 1566 & 3.809 & 8.013 & 5.54765 & .590511 \\
ATR & 1566 & .000 & 3.693 & .75676 & .535700 & .349 \\
ROA & 1566 & -1.245 & .542 & .03011 & .099548 \\
CURR & 1566 & .006 & .992 & .50333 & .200335 \\
DA & 1566 & .026 & 2.033 & .40569 & .207469 \\
BETA & 1566 & .062 & 2.094 & .96788 & .040 \\
\hline Valid N (listwise) & 1566 & & & & .040 \\
& & & & .1673 \\
\hline
\end{tabular}


Table 2 presents the basic descriptive statistic regression variables. Around 62\% (971/1566) of the sample companies were audited by Big Four audit firms. The high concentration rate in the auditing market could be due to the intention of the public listed company to increase investors' confidence due to the increase in corporate scandals over the years.

On the other hand, the largest shareholders can normally have infinite controlling power over the listed firms, holding a mean of $23.44 \%$ of the total equity shares of the sample public listed firms. This circumstance of monopolist shareholding has essentially led to poor corporate governance practices and raised serious concerns by investors, professionals, regulators, and the public (DeFond et al., 2000).

The average size of the BOD for the sample firms is 7.47 with a minimum BOD size of three (3) persons and the largest with 17 persons. In addition, about $23 \%$ of the sample firms $(360 / 1566)$ had the same person holding both positions of BOD Chairman and CEO. The results shows that about $77 \%$ of the firms (1206/1566) have a separate BOD chairman and CEO which would suggest better monitoring mechanism thus promote better firm performance. Furthermore, the average number of audit committee for the sample firms is 3.37 with minimum audit committee size of three (3) persons and the largest with six (6) persons.

Table 3: Correlation Matrix

\begin{tabular}{|c|c|c|c|c|c|c|c|c|c|c|c|c|c|}
\hline & & Constant & LSH & $\begin{array}{l}\text { AUDIT } \\
\text { COMMITTEE }\end{array}$ & DUALITY & BOD & NID & LNASSET & ATR & ROA & CURR & DA & BETA \\
\hline \multirow[t]{13}{*}{$\overline{\text { Step } 1}$} & Constant & 1.000 & & & & & & & & & & & \\
\hline & LSH & -.084 & 1.000 & & & & & & & & & & \\
\hline & AUDIT & -.244 & -.081 & 1.000 & & & & & & & & & \\
\hline & COMMITTEE & & & & & & & & & & & & \\
\hline & DUALITY & -.036 & -.050 & .059 & 1.000 & & & & & & & & \\
\hline & BOD & -.044 & .043 & -.066 & .046 & 1.000 & & & & & & & \\
\hline & NID & .120 & -.072 & -.149 & -.035 & -.533 & 1.000 & & & & & & \\
\hline & LNASSET & -.811 & -.020 & -.118 & -.036 & -.161 & -.146 & 1.000 & & & & & \\
\hline & ATR & -.201 & -.078 & .011 & -.040 & -.131 & .110 & .163 & 1.000 & & & & \\
\hline & ROA & .260 & -.050 & -.006 & -.018 & -.011 & .049 & -.281 & -.219 & 1.000 & & & \\
\hline & CURR & -.263 & -.044 & -.054 & .057 & .004 & -.006 & .106 & -.291 & -.069 & 1.000 & & \\
\hline & DA & .144 & .130 & .021 & .058 & .101 & -.020 & -.323 & -.253 & .313 & .049 & 1.000 & \\
\hline & BETA & .025 & .063 & .006 & -.059 & .151 & -.087 & -.249 & .177 & -.018 & -.014 & -.130 & 1.000 \\
\hline
\end{tabular}

Table 3 presents the correlation coefficient matrix. The choice of Big Four auditor is positively related to the audit committee size, largest ownership, firm risk, size of BOD, log of total asset (firm size) and return on asset. Correlation coefficients among the independent variables are not high with only one at the level of 0.360 (between number of independent director and log total asset), thus multicolinearity is low and will not have a significant effect on the relationship between the dependent and independent variables in the test model.

\section{LOGISTIC REGRESSION ANAL YSES}

Following the study done by Lin and Liu (2009), binary logistic regression was used to test the relationship between firms' internal corporate governance mechanisms and their audit choice decisions. Table 4 presents the results of the logistic regression of the model. 
Table 4: Variables in the Equation

\begin{tabular}{|c|c|c|c|c|c|c|c|}
\hline & & B & S.E. & Wald & df & Sig. & $\operatorname{Exp}(B)$ \\
\hline \multirow[t]{14}{*}{ Step $1^{\mathrm{a}}$} & LSH & .014 & .004 & 16.116 & 1 & .000 & 1.014 \\
\hline & AUDIT COMMITTEE & .180 & .095 & 3.581 & 1 & .058 & 1.198 \\
\hline & DUALITYY & -.460 & .126 & 13.430 & 1 & .000 & .631 \\
\hline & BOD & .063 & .035 & 3.262 & 1 & .071 & 1.065 \\
\hline & NID & -.214 & .070 & 9.372 & 1 & .002 & .807 \\
\hline & LNASSET & 1.235 & .133 & 85.533 & 1 & .000 & 3.437 \\
\hline & ATR & .572 & .118 & 23.407 & 1 & .000 & 1.771 \\
\hline & ROA & .307 & .620 & .245 & 1 & .620 & 1.359 \\
\hline & CURR & -1.063 & .289 & 13.519 & 1 & .000 & .346 \\
\hline & DA & -1.886 & .297 & 40.355 & 1 & .000 & .152 \\
\hline & BETA & .508 & .147 & 11.883 & 1 & .001 & 1.661 \\
\hline & Constant & -6.596 & 697 & 89.531 & 1 & .000 & .001 \\
\hline & LSH & B & S.E. & Wald & df & Sig. & $\operatorname{Exp}(\mathrm{B})$ \\
\hline & AUDIT COMMITTEE & .014 & .004 & 16.116 & 1 & .000 & 1.014 \\
\hline
\end{tabular}

a. Variable(s) entered on step 1: LSH, AUDIT_COMMITTEE, DUALITY, BOD, NID, LNASSET, ATR, ROA, CURR, DA, BETA.

The results show that duality of CEO, number of independent directors, asset structure (CURR) and firm leverage (DA) does not contribute to the model. The negative B indicates that the target group (audit quality) tends to have more of those coded "0" (non-Big Four) than of these coded "1" (Big Four) but not significantly, after controlling for the other predictors. Meanwhile, audit committee size, largest shareholders, firm risk (Beta), BOD size, firm size (log total asset), growth (asset turnover ratio) and profitability (return on asset) do contribute to the model. The positive B indicates that the target group (audit quality) tends to have more of those coded "1" (Big Four) than of these coded "0" (non-Big Four) but not significantly, after controlling for the other predictors.

The coefficient for the variable of ownership concentration (the largest owner's shareholding) is negatively correlated with audit quality. It advocate that with a larger portion of shares held by controlling owners, public listed firms would be less likely to choose a high quality (Big Four) auditor. The result is consistent with proposed H1 and study done by Lin and Liu (2009). The finding concede that with high concentration of ownership, firms opt for selecting a low level of external audit monitoring in order to profit from more aggressive earnings manipulation and 'tunnelling' behaviours even at the expense of the monitory shareholders or outside investors (Lin and Liu, 2009).

On the other hand, consistence with the proposed $\mathrm{H} 2$, the audit committee size is positively associated with audit quality $(\mathrm{B} 2=0.180$, Wald $=3.581)$. It indicates that, larger audit committee size will be more likely to choose a Big Four (high quality) auditor. The results reveal that an audit committee, which is a subcommittee for the board, plays an important role in the process of selecting external auditor. Effective audit committee, which is associated with audit committees that are active, independent, consist of accounting and industry experts as well as have more members, is a credible indication of strong corporate governance.

The coefficient for the variable of duality of CEO is negatively associated with audit quality $(B 3=-0.460$, Wald $=13.430)$. It shows that with when a CEO also holds the position as chairman of board, a listed firm is less likely to hire high quality (Big Four) auditors. It is consistent with 
proposed H3 of the study and in line with the study done by Lin and Liu, (2009). The finding signify that recent regulations in western countries that separate firms' CEO and BOD Chairman positions should be applicable to Malaysian listed firms as well. Such a measure is an effective arrangement for the BOD to oversee the performance of the management. This results contradict with stewardship theory and consistent with agency theory. It seems that, if two different persons hold the position of CEO and Board Chairman, there would be higher chances that a public listed company will select a high quality auditor to oversee and ensure the quality of firm's financial reporting process and management performance (Lin and Liu, 2009).

As indicated by B4, the BOD size is positively related to the selection of a Big Four auditor. The results suggest that firms with larger BOD size are more likely to choose a Big Four (high quality) auditor which supports $\mathrm{H} 4$ which proposed that smaller BOD size will be less likely to choose a high quality (Big Four) auditor. Our findings demonstrate that if there is a large BOD that relatively exhibits greater monitoring role; a firm may be more likely to employ a high quality (Big Four) auditor to enhance the supervision or monitoring role. Again, the finding of this study is consistent with those found by Lin and Liu (2009).

As for number of independent directors, our result shows that there is a negative connection between number of independent directors in the board and audit quality. The findings is contrast with proposed hypothesis 5 (H5) which suggest that the fewer the number of the independent directors, the less likely a firm will choose a high-quality (Big Four) auditor. The results advocate that, a large proportion of independent directors on the board would contribute to the firm choosing a lower audit quality (non-Big Four). Though prior study suggest otherwise, the negative association between those two maybe due to the desire of independent directors to protect their image by hiring lower quality auditor to enhance the possibility of earnings management and at the same time to reduce the likelihood of auditors found prove of material misstatement or financial irregularities in the financial statement.

For the control variables, firm size (log of total assets), firm specific risk (beta) and profitability (return on assets) are all positively related to the selection of Big Four (high-quality) auditors. Consistent with prior research in the developed markets, the results suggest that large firms, firms with greater risk and more profitable firms are inclined to hire high-quality (Big Four) auditors in the Malaysian stock market. As for asset structure (current asset divided by total asset) and financial leverage (debt to asset ratio) are negatively associated with the selection of Big Four (high quality) auditors. The finding suggests that high leverage firms and firms with greater asset structure would be more inclined to choose lower quality (non-Big Four) auditors.

\section{SUMMARY OF HYPOTHESES}

Table 5 provide overall summary of the hypotheses that has been tested above using descriptive and binary logistic regression.

Table 5: Summary of the hypotheses

\begin{tabular}{|c|c|}
\hline Hypotheses & Result \\
\hline H1 & Supported \\
\hline H2 & Supported \\
\hline
\end{tabular}




\begin{tabular}{|c|c|}
\hline H3 & Supported \\
\hline H4 & Supported \\
\hline H5 & Rejected \\
\hline
\end{tabular}

\section{CONCLUSION}

\section{DISCUSSION}

The findings of the study may create implications for the stakeholders of the Malaysian public listed especially the one who has direct impact, which is the investors as well market regulators. As weak internal corporate governance itself would probably shaken the public interest and could jeopardize a going concern of the firm in the future, it would not be a good practice for listed firms to choose low quality auditors. In doing so, the controlling shareholders of the listed firms can easily capture private profits from exploiting small shareholders. As such, to strengthen the confidence and trust of the market participants, the regulator should promote the reform of corporate governance of the listed firm, enforcing an effective functioning of the BOD as well as independent non-executive directors or subcommittees of the board (i.e. audit committee, risk and management committee, etc.) to continuously improve firms' internal and external supervision mechanisms thus enhancing transparency and information credibility of the listed firms.

\section{LIMITATION OF THE STUDY AND SUGGESTION FOR FUTURE RESEARCH}

There are some limitations in this study. First, more accurate results may be derived from more sophisticated simultaneous equation methods for the auditor choice test. Simultaneous equation method could be used to control both the demand and the supply effect of audit service. However, audit fee (a key variable to proxy for the supply effect in the audit market) was not included in this study. Perhaps, future study should explore on this matter. Second, the size of audit committee may not be a good proxy for internal corporate governance mechanisms since the sample chosen consists of public listed companies, which are governed by listing requirement of Bursa Malaysia that require them to have at least three members in the committee. Results found in the study shows that most of the listed firms have three members in the committee with a maximum of six members. Hence, the testing results may be more persuasive if we include the expertise of independent non-executive directors and other characteristics of audit committee.

\section{REFERENCES}

Ahmad, A. C., Houghton, K. A., \& Yusof, N. Z. M. (2006). The Malaysian market for audit services: ethnicity, multinational companies and auditor choice. Managerial Auditing Journal, 21(7), $702-$ 723.

Alnasser, S. (2012). What has changed? The development of corporate governance in Malaysia. The Journal of Risk Finance, 13(3), 269 - 276. 
Ashbaugh, H., \& Warfield, T. D. (2003). Audit as a corporate governance mechanism: Evidence from the German market. Journal of International Accounting Research, 2, 1-21.

Bardos, K. S. (2011). Quality of financial information and liquidity. Review of Financial Economics, 20(2), 49-62.

Bartlett, J. E., II , Kotrlik, J. W., \& Higgins, C. C. (Spring 2001). Organizational Research: Determining Appropriate Sample Size in Survey Research. Information Technology, Learning, and Performance Journal, 19(1).

Beattie, V., \& Fearnley, S. (1995). The Importance of Audit Firm Characteristic and the Drivers of Auditor Change in UK Listed Companies. Accounting and Business Research, 25(100), 227-239.

Chaney, P., Jeter, D., \& Shivakumar, L. (2003). Self-Selection of Auditors and Audit Pricing in Private Firms.

DeFond, M. L., Wong, T. J., \& Li, S. (1999). The impact of improved auditor independence on audit market concentration in China. [doi: 10.1016/S0165-4101(00)00005-7]. Journal of Accounting and Economics, 28(3), 269-305.

Eugene A. Imhoff, J. (January 2003). Accounting Quality, Auditing and Corporate Governance.

Fama, E. F., \& Jensen, M. C. (1983). Separation of Ownership and Control. Journal of Law and Economics, XXVI.

Fields, T. D., Lys, T. Z., \& Vincent, L. (2001). Empirical research on accounting choice. Journal of Accounting and Economics, 31(1, Äi3), 255-307.

Guedhami, O., Pittman, J. A., \& Saffar, W. (2009). Auditor choice in privatized firms: Empirical evidence on the role of state and foreign owners. Journal of Accounting and Economics, 48, 151171.

Hope, O.-K., Kang, T., Thomas, W., \& Yoo, Y. K. (2008). Culture and auditor choice: A test of the secrecy hypothesis. J. Account. Public Policy, 27, 357-373.

Johnson, W. B., \& Lys, T. (1990). The market for audit services: Evidence from voluntary auditor changes. Journal of Accounting and Economics, 12(1, Äi3), 281-308.

La Porta, R., Lopez-de-Silanes, F., Shleifer, A., \& Vishny, R. (2000). Investor protection and corporate governance. Journal of Financial Economics, 58(1,Ä̀2), 3-27.

Lin, Z. J., \& Liu, M. (2009). The impact of corporate governance on auditor choice: Evidence from China. [doi: 10.1016/j.intaccaudtax.2008.12.005]. Journal of International Accounting, Auditing and Taxation, 18(1), 44-59.

Linda Elizabeth, D. (1982). Mandated successful efforts and auditor choice. Journal of Accounting and Economics, 4(3), 171-203.

Mahdavi, G., Maharlouie, M. M., Ebrahimi, F., \& Sarikhani, M. (2011). The Impact of Corporate Governance on Auditor choice. International Research Journal of Finance and Economics(68). 
MCCG. (2012). MALAYSIAN CODE ON CORPORATE GOVERNANCE 2012. Securities Commission Malaysia.

Nurwati, A. A.-Z., \& Wan Nordin, W.-H. (2010). Corporate governance and earnings forecasts accuracy. Asian Review of Accounting, 18(1), 50-67.

Pittman, J. A., \& Fortin, S. (2004). Auditor choice and the cost of debt capital for newly public firms. Journal of Accounting and Economics, 37(1), 113-136.

Rainsbury, E. A., Bradbury, M., \& Cahan, S. F. (2009). The impact of audit committee quality on financial reporting quality and audit fees. Journal of Contemporary Accounting \&amp; Economics, 5(1), 20 - 33.

Samad, F. A. (2002). Ownership Structure In The Malaysian Corporation Sector: Its Impact On Corporate Governance, Performance, Financing And Investment Patterns.

Shanthy, R., \& Elsa, S. (2009). Improving corporate governance of SMEs in emerging economies: a Malaysian experience. Journal of Enterprise Information Management, 22(4), 468-484.

Wallace, W. A. (2004). THE ECONOMIC ROLE OF THE AUDIT IN FREE AND REGULATED MARKETS: A LOOK BACK AND A LOOK FORWARD. Research in Accounting Regulation, 17(0), 267-298.

Wang, Q., Wong, T. J., \& Xia, L. (2008). State ownership, the institutional environment, and auditor choice: Evidence from China. Journal of Accounting and Economics, 46, 112-134. 